\title{
Application of Experiental Learning Model in History Learning
}

\author{
$1^{\text {st }}$ Corry Liana \\ Education History Departement \\ Universitas Negeri Surabaya \\ Surabaya, Indonesia \\ email: corryliana@unesa.ac.id
}

\author{
$2^{\text {nd }}$ Nasution \\ Education History Departement, \\ Universitas Negeri Surabaya \\ Surabaya, Indonesia \\ email: nasution@unesa.ac.id
}

\author{
$3^{\text {rd }}$ Septina Alrianingrum \\ Education History Departement, \\ Universitas Negeri Surabaya \\ Surabaya, Indonesia \\ email: septi@unesa.ac.id
}

\begin{abstract}
The era of globalization is an inevitable period. Therefore, the Institute for Educational Teaching (LPTK), especially historical education must be able to answer the challenge by applying learning innovation. LPTK has the task of preparing professional teachers, who are able to educate the young generation as the future successors. Teachers are professional positions demanding academic, pedagogical, social, and professional requirements. This study aims to analyze the application of learning experiential learning model in history learning at the State University of Surabaya, especially in the Department of History education. Learning experiential models not only involve students in activities, but help to elicit the meaning of these activities, resulting in knowledge that can later be transformed to students, when they become history teachers.
\end{abstract}

Keywords: experiential learning and history education.

\section{INTRODUCTION}

Almost for 30 years, Institute of Management (IMD) has been lead on the research on how create talented and skilled workers in the world and evaluated the country which is maintain them for being participate in the economy in their country, IMD collaborate with 57 institutions partner around the world, to provide the data for community, education institution, government and company. There are 3 indicators which used in this research, the first one is the development and investment, the attractiveness of the country, and the readiness of human resources.

Indonesia is one of the country that follow the IMD survey from 63 countries in the world, in 2017 Indonesia ranked in the position number 47, down 3 points from 2016 and left behind from neighboring countries, for example Malaysia, Singapore and Thailand.[1] Based on first indicator Indonesia was ranked 56th, ranked 32th for the second indicator, and ranked 47 th for the third indicator. Refer to the third indicator from the year IMD research 2017, concerning the readiness of human resources, Indonesia is still not on the preparing human resources. This is reflected in several indicators. The other indicators such as system education and education at the university level, are ranked above 40, only the educational indicators of science in school with rank 34.

The weakness of human resource readiness is homework for the education system in Indonesia. The university has an important role to produce human resource to be able to compete and provide labor which has the capabilities needed by the world of work. the Institute for Educational Teaching (LPTK) as a college institution has a very big role to produce professional teachers.

Teacher professionalism is a necessity that cannot be postponed, considering the increasing competition in the era of globalization, including teachers as professions demanding to the qualification and professional skills. Professionalism requires sufficient seriousness and competence adequately, the someone considered worthy the organize the right task.[2] Essentially, the development teacher professionalism is emphasized on three basic skills, namely; profession ability, personal ability and social ability. Professional competition, in National Education Standards, section 28 paragraph (3) item c declare that the definition of professional competence is the ability of mastering learning materials widely and deeply that allows guiding learners to meet the standards of competence specified in the National Education Standards.

Mastery of material by the teacher has a very large role in learning outcomes obtained by students. According to, learning outcomes include 3 (three) domains: 1) the cognitive domain, where the focus of this domain is on the ability to think, remember, and solve problems; 2) affective domain, related to value, attitude, interest, and appreciation, while 3) domain psychomotor is related to motor skills and stringing.[3] Student learning outcomes influenced by several factors for example, the quality of interaction among students, materials, and teachers, as well as characteristics of students at the time of learning. Teachers who have high mastery of material competence are expected to be able to teach all the subject matter to students thoroughly and optimally to achieve the expected learning outcomes.

Based on the background above, it is expected that students of the Department of History Education UNESA have the ability to understand the material well, so that they can become professional teachers, and to be able to produce the nation's successors who are ready to face the era of globalization. The method used is experiential learning method, whose learning is more focused in 
providing active learning experiences. Learning through experience is not a new concept for college classes. Wellknown educational psychologists such as John Dewey, have provided the foundation of learning theory that focuses on "learning through experience" or learning by doing. "Dewey popularized the concept of experiential learning focusing on problem solving and critical thinking rather than memorization.[4] Kolb also noted that concrete learning experiences are essential for meaningful and wellknown learning for Learning Style Inventory (LSI) that helps identify preferred learning styles.[5]

\section{RESEARCH METHODS}

A. Type of research

The research method used is quasi-experimental with the research design used is a one-shot case study, in which a group is subjected to a certain treatment and then measures the dependent variable. The research design used in this study is the design of one shot case study. Fraenkel and Wallen, stated the chart of a one-shot case study is as follows.[6]

Table 1. One Shot Case Study

\begin{tabular}{|c|c|}
\hline X(Treatment) & O \\
\hline Treatment of independent & Observation or \\
variable (Treatment of & measurement of \\
independent variable) & dependent variable \\
& (Observation or \\
& measurement of \\
& dependent variable) \\
\hline
\end{tabular}

The chart can be read as follows: there is a group that is treated, and then observed. $\mathrm{X}$ is the class that will be given a stimulus in the experiment and $\mathrm{O}$ is the event of measurement or observation. In this research, the class that is treated is the application of experiential learning model.

\section{B. Research Subject}

The subjects of this research are student 2016 class A Department of History Education State University of Surabaya which is taking the course of History of East Asia, which amounted to 45 students. The subject of this study was used to measure the achievement of learning by using experiential learning.

\section{Data Collection and Analysis Techniques}

Data retrieval technique in the form of a test of understanding of material in East Asian history and learning activities of students, while participating in learning using the method experiential learning. The test results will use the criteria assessment at UNESA, such as, values between 85-80 (A), 79-75 (B +), 74-70 (B), 69-65 (B-), 64-60 (C +), 59 -55 (C-), and 54-50 (D). For calculating the observation sheet, it is using a percentage formula. Formula percentage used is:

$$
P=\frac{n}{N} x 100 \%
$$

Information:

P: Final Value (percentage)

$\mathrm{n}$ : Reality value of the result in questionnaire

$\mathrm{N}$ : Maximum value, i.e. the number of respondents multiplied by the highest value

\section{RESULTS AND DISCUSSION}

Colin (2006), mention experience-based learning (experiential learning) can build knowledge, skills, and attitudes through experiences, that beneficial for the learners.[7] According Fathurrahman (2015), Experientisl Learning is the learning process which is Lerner centered, activity oriented, and learners can apply what had been gained from the experience.[8]

Experiential learning as a process in which the transformation of experience results in the creation of new knowledge, by teachers designing active learning and applying two-way communication between teachers and students, and students with another student. Experimental learning involves a number of steps that offer students direct, collaborative and reflective learning experiences that help them to "fully learn new skills and knowledge".[9]

In historical education apply experiential learning which has the potential to provide students with extensive opportunities to develop historical thinking skills, such as the ability to identify continuity and change concept, analyze the causes and effects of historical events, understand how to make historical interpretations, by using primary source evidence and taking perspective history. Experiential education is a learning that is prioritizing learning activities, meaningful learning that can be applied, easy to remember and fun for learners, thus the knowledge gained has the opportunity to be stored in the brain in long term memory.

Learning activities are student involvement in attitude, mindset, attention and learning activities that can support the success of a process learning. According to Paul D. Dierich, activity has 8 groups classified by type of visual, Oral (oral), listening, writing, drawing, metrics, mental and emotional. Given the number the type of activity observed,[10] in this study researchers took the type of activity in accordance with Experiential Learning and step by step in the study of history (Heuristics, verification, interpretation and historiography). Therefore, the activity to be observed becomes indicators of research are as follows;

Table 2. Experiential learning indicators

\begin{tabular}{|c|l|l|}
\hline No & \multicolumn{1}{|c|}{ Student activity } & \multicolumn{1}{c|}{ Activity Type } \\
\hline 1 & Do a source search & Visual and writing \\
\hline 2 & Express opinions & oral \\
\hline 3 & $\begin{array}{l}\text { Record important / relevant } \\
\text { matters }\end{array}$ & $\begin{array}{l}\text { Writing } \\
\text { (observation sheet) }\end{array}$ \\
\hline 4 & Solve problems in groups & Writing (test) \\
\hline 5 & $\begin{array}{l}\text { The courage to ask and } \\
\text { replied }\end{array}$ & $\begin{array}{l}\text { verbal and } \\
\text { emotional }\end{array}$ \\
\hline
\end{tabular}


The quality of experiential learning, lies in the experience of students when deciding for themselves to engage personally in the learning experience (students actively participate in their own learning and have a personal role in the direction of learning). In the first phase of the study, the class was divided into 5 theme groups, with a total of 9 students. Each individual in the theme group is required to complete individual tasks and group task. Based on figure 1 , it is found that $50 \%$ of students have been able to collect resources, according to the case studies they get. Lecturer in this case, provides a project journal, which must be completed with how many sources they have obtained.

\section{Picture 1. Experiential learning Outcomes}

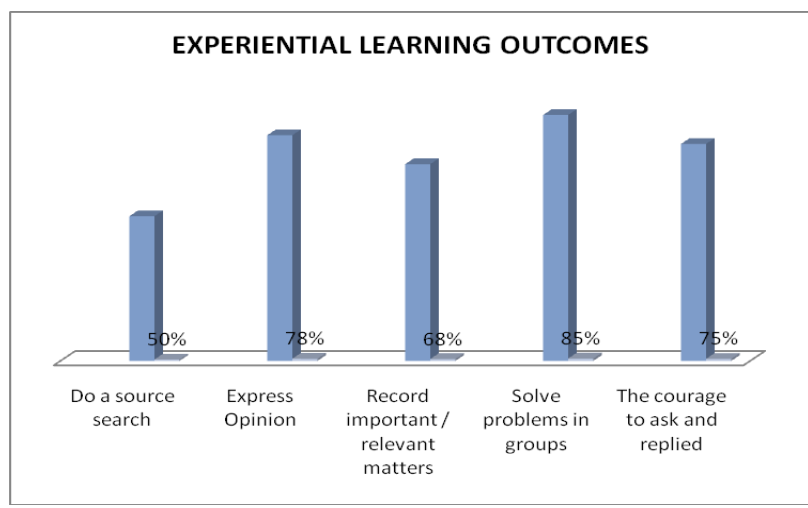

Giving project journal to student is one of assessment strategy in experiential learning, because one of the indicators in this learning is how lecturers can create a challenging atmosphere or situation in learning process [11] , so their knowledge or skill can be stored in long term memory.

In the second activity, students have been able to express their personal opinions in group discussions or in class discussions. As many as $78 \%$ of students have conducted opinions (between 8-15 times), and $15 \%$ of students succeeded in raising opinions as much as 4-7 times, and the remaining $8 \%$ of students, expressing opinions 1-3 times. The courage of students in expressing opinions is one of the goals of experiential learning. Bartle, said that universities need to prepare students to contribute to local, national or international organizations. [12] The contribution, begins with a courageous way of expressing his opinion publicly, and based on some evidences or references, it is also one of the "21st century skills", in addition to the core discipline knowledge in their chosen field.

Conducted to the research by Yates, Wilson, and Purton, where the evaluation of experiential learning is different with evaluation conventional learning. The type of evaluation used, is emphasizes more on how the teacher assesses the learning process undertaken by students, some of the evaluation form that often used are from journals, reports, group projects, presentations and selfevaluations. The project journal, as described in Activity 1, contains several components that can assess the learning process carried out by students, one component of which is the part that records important things at each meeting

During the process discussion, the students are required to write the important points that they find and what will they do. There are $68 \%$ students make a note to what they get during the learning, but only $32 \%$ students are not pay attention to write the important points. The student who don't give their attention to the material is based on the habit in previous learning which more dominated by assessments conducted at the end of learning, that's why students choose passively during the learning process.

The third activity of experiential learning is the most important part of self-development that must be carried out by students, as a contribution to the progress of the group. [13] The role of the individual is one of the most important factors in Experiential learning, because, individuals must be given the opportunity to gain learning experience, until the knowledge they get can be meaningful knowledge. Kolb, also explained that experiential learning is based on the idea that individual activity, education, and work play a central role in their learning and understanding of new knowledge.

Experimental learning can be used as a teaching method to support higher education which is more dominant in appreciating students in learning in various contexts based on university, project, work-integrated and community. The process of knowledge is done by resolving cases based on the theme which is shared by lecturer, individually, then the results discussed again in the theme groups. According to Gentry's research, that experiential learning is participatory and interactive, therefore learning can also be applied in the form of working groups. [14]

Based on the fourth activity result, solving the problem in the group, student class of Class A 2016, has been able to solve problems in the group. As many as $85 \%$ of students are able to formulate the results of the problems given by the lecturers, in this stage each individual, should submit a temporary discovery of the case study they are finalizing, with applying the evidences (First Activity). The theme group, then gathered the various existing inventions, and considering the evidence. The fourth activity gets a high point, because in the fifth activity, students are seen to be courageous in asking and answering, and make the discussion become interactive and communicative.

Data collection was carried out in the fifth activity, based on activities in the theme group, and class groups. Discussions in class groups, carried out by means of each group must present the results of their discussions with the duration that have been given. The result is about $75 \%$ of the students have been brave enough to express their opinions, even though the most results are in class discussions. The results of data include high data, considering the students who always follow their friend opinion. 
Picture 2. The Results Of The Assessment Of Papers

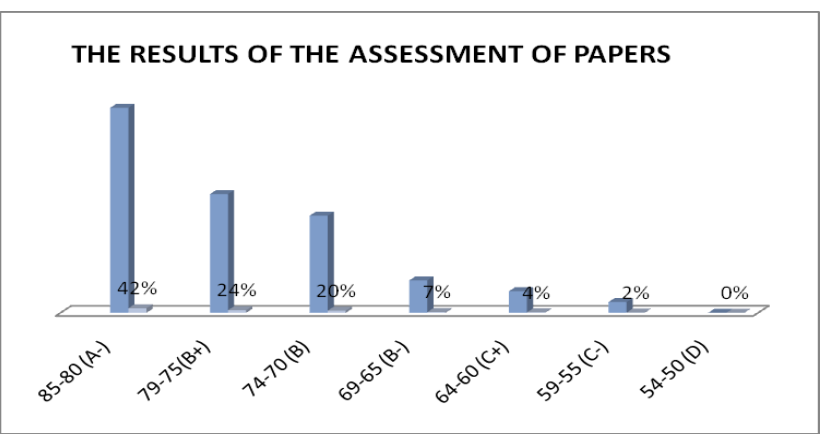

According to Shulman 1986, one of teacher competence is knowing the subject of contain knowledge (history) which is supported by media technology. Harlen \& Holroyd (1997) argue that the teacher understanding of material will impact to the decision of making learning strategies.[15] To create a better learning, the teacher who have a good content of learning will be able to construct some materials elements simultaneously in working memory. [16] Contain knowledge which is owned by department of Education History of UNESA can be seen from the result of the work in the form of paper.

From the data above can be conclude that $42 \%$ of student have been able get score between 80-85 (A-), and 24\%get 79-75 $(\mathrm{B}+)$. The assessment of the paper it is not only student ability in analyzing, but depend also on how the student can evaluate the history of countries in East Asia. Which is can impact to the system of politic and economy in the world. The evaluation that the students do, it is no separated from the historical sources which is used (activity 1), consists of primary sources secondary sources.

\section{CONCLUSION}

Based on the result of data analysis, it is found that experiential learning is running very well, it can be seen from some of the achievement indicators which is more than $50 \%$. Generally, the students are more understand the history of East Asia, because they do some activities which is the process always be monitored by the lecturers and every evaluation are always report to the student, as material improvement. The other things that seen in experiential learning, is the understanding of the material is to be better, almost $42 \%$ get an A-. The implementation of experiential learning suitable applied to the higher education, it is more on the activities, because the students need to learn how to solve the problem in the real situations.

\section{REFERENCES}

[1] I. M. D. World, "IMD WORLD TALENT."

[2] G. A. T. dan N. T. Agustiana, Konsep Dasar IPA. Yogyakarta: Ombak, 2013.

[3] B. S. Bloom, Taxonomy of Educational Objectives: The Classification of Educational Goals, Handbook I Cognitive Domain. New York: Longmans, Green and Co, 1956.

[4] J. Dewey, Democracy and Education. New York: Macmillan, Originally Published, 1916.

[5] D. A. Kolb and R. E. Boyatzis, "No Title," no. 216, 2000.

[6] N. Fraenkel, J., Wallen, How to Design and Evaluate Research in Education. New York: McGraw-Hill Higher Education, 2008.

[7] W. Colin, Experiential Learning. A Best Practice handbookfor educationand trainers. London and Philadelpia: Kogan Page., 2006.

[8] Fathurrahman, Model-model Pembelajaran Inovatif. Yogjakarta: Ar-Ruzz Media, 2015.

[9] C. Haynes, "Experiential learning: Learning by doing: 5-step experiential learning cycle definitions," University of California Davis, 2007. [Online]. http://www.experientiallearning.ucdavis.edu/module1/el1_405stepdefinitions.pdf.

[10] P. D. Dierich, Classroom Management For Secondary Teachers. New Jersey: Prentice Hall, Inc, 2011.

[11] T. Yates, J. Wilson, and K. Purton, "Surveying Assessment in Experiential Learning: A Single Campus Study Surveying Assessment in Experiential Learning: A Single Campus Study," vol. 6 , no. 3,2015 .

[12] J. Wright and D. Vice-, "Experiential learning: an overview A discussion paper prepared for," 2015.

[13] C. Rogers, "Experiential Learning," 2010

[14] J. W. Gentry, "CHAPTER 2 WHAT IS EXPERIENTIAL LEARNING ?,” pp. 9-20, 1990.

[15] C. Harlen, W., \& Holroyd, "Primary Teachers' Understanding of Concept of Science: Impact on Confidence and Teaching," Int. J. Sci. Educ., vol. 19, pp. 93-105, 1997.

[16] P. Koehler, M.J \& Mishra, Handbook Technological Pedagogical Content knowledge For Educations. Routledge, 2008. 